\title{
Implementasi Good Corporate Governance, Budaya Organisasi dan Kinerja Manajerial pada Hotel Berbintang di Kabupaten Badung
}

\author{
Ni Wayan Prita Wanda Hilldayani ${ }^{1}$ \\ Fakultas Ekonomi dan Bisnis \\ Universitas Udayana, Indonesia
}

\author{
Ni Putu Sri Harta Mimba ${ }^{3}$ \\ Fakultas Ekonomi dan Bisnis \\ Universitas Udayana, Indonesia
}

\author{
I Gusti Ayu Made Asri Dwija Putri² \\ Fakultas Ekonomi dan Bisnis \\ Universitas Udayana, Indonesia
}

\author{
Ni Gusti Putu Wirawati ${ }^{4}$ \\ Fakultas Ekonomi dan Bisnis \\ Universitas Udayana, Indonesia
}

\begin{abstract}
Surel : wandaprita@gmail.com
ABSTRAK

Kinerja merupaka hasil kerja yang dapat diraih oleh seseorang atau kelompok di perusahaan sesuai dengan wewenang dan tanggung jawab dalam upaya mencapai tujuan perusahaan. Kabupaten Badung memiliki jumlah hotel berbintang terbanyak di Bali. Banyak faktor yang dapat mempengaruhi kinerja diantaranya adalah Good Corporate governance (GCG) dan budaya organisasi. Tujuan penelitian adalah mengetahui pengaruh perinsip GCG dan budaya organisasi terhadap kinerja manajerial. Penelitian dilakukan di 61 hotel berbintang yang ada di Kabupaten Badung. Teknik analisis data yang digunakan adalah analisis regresi linear berganda. Penelitian ini menunjukkan hasil bahwa variabel Independensi dan Budaya Organisasi berpengaruh positif terhadap kinerja manajerial, sedangkan variabel Transparansi, Akuntabilitas, Responsibilitas dan Kewajaran tidak berpengaruh terhadap kinerja manajerial.

Kata Kunci: Kinerja Manajerial; Good Corporate Governance; Budaya Organisasi.

Implementation of Good Corporate Governance, Organizational Culture and Managerial Performance at Star Hotels in Badung Regency
\end{abstract}

\section{ABSTRACT}

Performance is the result of work that can be achieved by a person or group in the company in accordance with the authority and responsibility in an effort to achieve company goals. Badung Regency has the most number of star-rated hotels in Bali. Many factors can affect performance including Good Corporate governance (GCG) and organizational culture. The research objective is to determine the effect of GCG principles and organizational culture on managerial performance. The study was conducted in 61 star hotels in Badung Regency. The data analysis technique used is multiple linear regression analysis. This study shows the results that the variable Independence and Organizational Culture has a positive effect on managerial performance, while the variables Transparency, Accountability, Responsibility and Fairness do not affect managerial performance.

Keywords: Managerial Performance; Good Corporate Governance; Organizational Culture.

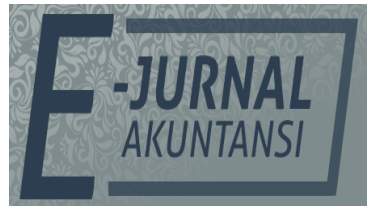

e-ISSN 2302-8556

Vol. 31 No. 10

Denpasar, Oktober 2021

Hal. 2453-2466

DOI:

10.24843/EJA.2021.v31.i10.p04

PENGUTIPAN:

Hilldayani, N.W.P.W., Putri,

I.G.A.M.A.D., Mimba,

N.P.S.H., \& Wirawati, I.G.P.

(2021). Implementasi Good

Corporate Governance, Budaya

Organisasi dan Kinerja

Manajerial pada Hotel

Berbintang di Kabupaten

Badung. E-Jurnal Akuntansi, 31(10), 2453-2466

RIWAYAT ARTIKEL:

Artikel Masuk:

12 Desember 2019

Artikel Diterima:

22 Januari 2020

Artikel dapat diakses : https://ojs.unud.ac.id/index.php/Akuntansi/index 


\section{PENDAHULUAN}

Bali merupakan salah satu destinasi wisata yang paling diminati di Indonesia. Bali memiliki daya tarik tersendiri bagi para wisatawan lokal hingga mancanegara. Pemerintah menyadari bahwa pariwisata memegang peranan penting bagi pertumbuhan ekonomi yang ada di setiap daerah. Salah satu fasilitas yang dapat menunjang kenyaman para wisatawan adalah hotel. Bali sebagai destinasi wisata yang memiliki beragam obyek wisata memerlukan hotel dengan sarana dan prasarana yang baik untuk para wisatawan. Hotel adalah salah satu bisnis yang dapat penunjang perkembangan pariwisata dengan demikian hotel dituntut untuk memiliki kinerja yang baik, (Utami et al., 2017) Badan Pusat Statistik Kabupaten Badung, (2018), menyatakan bahwa terdapat 248 hotel berbintang yang ada di Bali. Di Kabupaten Badung sendiri terdapat 156 Hotel Berbintang yang merupakan jumlah hotel terbanyak di Bali.

Data dari Badan Pusat Statistik Kabupaten Badung menunjukkan terdapat peningkatan tingkat penghunian kamar yang ada pada hotel berbintang di Kabupaten Badung dari tahun 2017 hingga tahun 2018. Hal ini menunjukkan bahwa Kabupaten Badung telah mampu menarik wisatawan dengan potensi obyek wisata yang dimilikinya sehingga secara tidak langsung akan mempengaruhi kinerja hotel berbintang di Kabupaten Badung. Berikut ini merupakan gambaran rata-rata tingkat penghunian kamar di Kabupaten Badung pada tahun 2017-2018 sebagai berikut.

Tabel 1. Tingkat Penghunian Kamar (TPK) untuk Hotel Berbintang menurut Bulan di Kabupaten Badung, Tahun 2017-2018

\begin{tabular}{llll}
\hline No & Bulan & 2017 & 2018 \\
\hline 1 & Januari & 64,94 & 55,62 \\
2 & Februari & 65,57 & 70,32 \\
3 & Maret & 60,97 & 64,87 \\
4 & April & 60,66 & 66,71 \\
5 & Mei & 64,68 & 71,44 \\
6 & Juni & 70,21 & 73,79 \\
7 & Juli & 76,01 & 74,95 \\
8 & Agustus & 77,49 & 74,94 \\
9 & September & 78,76 & 71,42 \\
10 & Oktober & 69,41 & 70,07 \\
11 & November & 57,64 & 58,11 \\
12 & Desember & 54,69 & 59,38 \\
\multicolumn{2}{l}{ Tahunan/Rata-rata } & 66,75 & 67,64 \\
Sumber : Badan Pusat Statistik Kabupaten Badung, 2018 & \\
ada pada hotel. Kinerja manajerial juga turut mempengaruhi jumlah wisatawan \\
yang menginap pada hotel, semakin baik kinerja manajerialnya maka wisatawan
\end{tabular}


akan semakin betah untuk menginap di hotel. Kinerja perusahaan tidak dapat dilepaskan dari kinerja manajemen perusahaan itu sendiri, (Pradnyaswari \& Putri, 2016).

Kinerja bila dikaitkan dengan performance sebagai kata benda akan menghasilkan definisi kinerja merupakan hasil usaha seseorang atau suatu organisasi dalam perusahaan sesuai dengan wewenang dan tanggung jawab dalam upaya mencapai tujuan organisasi. Faktor yang diduga dapat memengaruhi kinerja manajerial yaitu implementasi prinsip-prinsip Good Corporate governance (GCG). Prinsip-prinsip Good Corporate governance (GCG) ada empat yakni akuntabilitas, transparansi, responsibilitas, serta kewajaran, (Zakaria et al., 2014). Manajemen dan pengelolaan perusahaan di era perekonomian modern seperti saat ini semakin banyak dipisahkan dari kepemilikan perusahaan. Hal tersebut memiliki tujuan agar pemilik perusahaan mendapat keuntungan yang semaksimal mungkin dengan mengeluarkan biaya yang seefisien mungkin dengan tenaga professional yang mengelola perusahaannya. Terdapat perbedaan kepentingan diantara pengelolaan dan kepemilikan perusahaan dapat menimbukan terjadinya konflik yang biasa disebut konflik keagenan. Konflik keagenan bisa ditekan oleh prinsip GCG yang kemudian dapat meningkatkan kinerja manajerial, (Azeez, 2015). Menurut Oliver \& Horngren, (2010), corporate governance terjadi dalam organisasi dikarenakan oleh adanya masalah agensi atau konflik kepentingan yang melibatkan anggota organisasi. Menurut Messier et al., (2012), hubungan keagenan ini menimbulkan dua permasalahan yaitu, terjadinya asimetri informasi dan konflik kepentingan. Menurut Clemente \& Labat (2009), corporate governance adalah suatu mekanisme pengendalian internal yang paling penting dari masalah lembaga dalam mengurangi salah satu dampak dari hubungan keagenan yaitu asimetri informasi. Manajer selaku penanggungjawab perusahaan biasanya lebih fokus pada proyek serta investasi yang dapat memberikan laba yang tinggi pada tempo yang singkat, hal ini tidak sejalan dengan pemilik perusahaan yang lebih ingin memaksimalkan kesejahteraan pemegang saham dengan investasi di proyek-proyek yang dapat memberi keuntungan dengan tempo yang lebih panjang (Megawati et al., 2017). Disebuah perusahaan baik yang bersifat profit oriented ataupun perusahaan nirlaba selama telah ada penyerahan pengelolaan tugas - tugas organisasi kepada pihak lain maka agency theory (teori keagenan) akan terjadi di dalam organisasi tersebut, (Sugiyanto, 2011). Profitabilitas perusahaan adalah hal penting guna mencapai kesuksesan serta kelangsungan hidup perusahaan (Yazdanfar, 2013). GCG berperan penting untuk menekan konflik antara pihak pengelola hotel (agen) dengan pihak yang berkepentingan (principal). Apabila tata kelola perusahaan telah baik maka hal itu bisa menujukkan kecenderungan tanggung jawab organisasi lebih besar, Rambo, (2013). Kinerja Manajerial menurut Mahoney, (1987) adalah seberapa jauh manajer mampu melaksanakan fungsi-fungsi manajemen. Manurut Organization for Economic Cooperation and Development (OECD), corporate governance yakni suatu sistem dapat dipakai sebagai pengarah dan pengendali aktivitas usaha sebuah organisasi, El-Chaarani, (2014).

Budaya organisasi juga memiliki pengaruh pada kinerja manajerial, Nurani, (2012). Budaya organisasi adalah kepercayaan seluruh karyawan pada sistem nilai dan yang ditetapkan, dikembangkan, serta dipelajari dengan berkelanjutan, 
berguna untuk pemersatu, serta bisa digunakan sebagai landasan dalam bertindak pada perusahaan untuk mencapai tujuan perusahaan yang sudah disepakati, (Temaja \& Utama, 2016). Wallach \& Ellen, (1983) berpendapat, budaya organisasi dipakai untuk sebuah pedoman oleh semua karyawan untuk meyakinkan semua yang terjadi di lingkungan bisnis. Perbedaan budaya dalam suatu organisasi secara signifikan dapat mempengaruhi kinerja manajerial dalam perusahaan tersebut, Tseng (2010). Robbins et al., (2010) menyatakan bahwa kekuatan budaya perusahaan menghasilkan kinerja perusahaan yang baik, karena dianggap bahwa budaya yang kuat merupakan budaya yang dapat menanamkan nilai-nilai utama dengan kuat dan dapat diterima secara luas dikalangan para pegawai.

Penelitian-penelitian tentang pengaruh Good Corporate Governace terhadap kinerja sudah banyak dilakukan. Wirawan \& Putri (2018) dalam penelitiannya menyatakan bahwa prinsip-prinsip GCG berpengaruh positif terhadap kinerja. Hasil dari penelitian itu sama dengan penelitian yang dilakukan Putri \& Putra, (2017) yang berpendapat bahwa prinsip-prinsip GCG memiliki pengaruh positif terhadap kinerja. Sari, (2017) dalam penelitiannya juga menyatakan bahwa prisip GCG berpengaruh positif terhadap kinerja.

Berdasarkan uraian latar belakang masalah yang telah dijabarkan, maka rumusan masalah dari penelitian ini adalah apakah transparansi, akuntabilitas, responsibilitas, independensi, kewajaran, dan budaya organisasi berpengaruh terhadap kinerja manajerial pada hotel berbintang di Kabupaten Badung. Tujuan dari penelitian ini adalah diharapkan dapat menjadi acuan bagi manajer di perusahaan atau hotel yang ingin mengetahui pentingnya implementasi prinsipprinsip tata kelola perusahaan bagi kinerja manajerial di perusahaan atau hotel.

Penelitian ini menggunakan Agency theory sebagai terori utama dan Stewardship Theory sebagai teori pendukung. Teori agensi adalah teori yang dirancang dengan melihat hubungan keagenan antara agen dan principal, (Jensen \& Meckling, 1976). Teori agensi ini menggambarkan pemilik sebagai principal, sedangkan manajer sebagai agen. Hubungan keagenan diartikan sebagai suatu kesepakatan antara satu atau lebih pihak principal yang mempekerjakan agen, dan agen diharapkan bisa melakukan beberapa pelayanan atas nama principal. Teori agensi menggambarkan bahwa dimana agen memiliki wewenang untuk mengelola perusahaan dan mengambil keputusan atas nama investor.

Teori stewardship merupakan keadaan manajer yang terdorong atas tujuan utama untuk keperluan perusahaan bukan terdorong oleh keperluan pribadi menurut Donaldson \& Davis, (1991). Teori tersebut memberikan pandangan keadaan manajer tidak terdorong dengan tujuan pribadi namun fokus dengan tujuan utama demi keperluan perusahaan, Riyadi \& Yulianto (2014). Para pihak manajemen sebagai steward termotivasi untuk berprilaku sesuai dengan keinginan prinsipal, selain itu steward tidak akan pergi meninggalkan organisasinya karena steward berusaha mencapai sasaran organisasi, Riyadi \& Yulianto, (2014).

Eisenhardt, (1989) berpendapat bahwa asumsi salah satu teori keagenan merupakan asumsi mengenai sifat manusia yang lebih sering bertindak untuk menguntungkan dirinya sendiri atau oportunistik. Sejalan dengan teori agensi, penerapan prinsip GCG salah satunya yaitu transparansi disebuah perusahaan 
dapat meminimalisir sifat oportunis dari manajemen maka akan berimbas kepada perbaikan kinerja suatu perusahaan. Transparansi secara sederhana menggambarkan sikap keterbukaan dalam menjalankan seluruh kegiatan operasional organisasi. Informasi yang relevan dan material serta mudah diakses harus mampu disediakan oleh perusahaan. Berdasarkan hal tersebut, maka peneliti mengajukan hipotesis pertama yaitu sebagai berikut.

$\mathrm{H}_{1}$ : Transparansi berpengaruh positif terhadap kinerja manajerial pada hotel berbintang di Kabupaten Badung.

Akuntabilitas merupakan pemahaman dari setiap komponen di dalam organisasi mengenai wewenang dan tanggung jawabnya dalam sebuah organisasi. Fungsi pelaksanaan dan tanggung jawab yang jelas akan membuat pengelolaan perusahaan menjadi lebih efektif yang nantinya kemudian menaikkan kinerja perusahaan. Didasari hal tersebut, maka peneliti mengajukan hipotesis kedua yaitu sebagai berikut.

$\mathrm{H}_{2}$ : Akuntabilitas berpengaruh positif terhadap kinerja manajerial pada hotel berbintang di Kabupaten Badung.

Resposibilitas adalah sikap organisasi didalam menjalankan organisasinya didasarkan peraturan dan undang-undang. Organisasi harus mematuhi peraturan yang berlaku serta menjalankan tanggung jawabnya kepada stakeholder agar usahanya dapat berjalan secara berkelanjutan. Hal ini juga terkait dengan citra perusahaan yang nantinya dapat menaikan kinerja organisasi. Berdasarkan pernyataan tersebut, maka peneliti mengajukan hipotesis ketiga yaitu sebagai berikut.

$\mathrm{H}_{3}$ : Responsibilitas berpengaruh positif terhadap kinerja manajerial pada hotel berbintang di Kabupaten Badung.

Independensi adalah suatu sikap organisasi didalam pengambilan keputusan secara bebas tanpa adanya tekanan atau intimidasi dari pihak luar. Kebebasan penting untuk diperhatikan sebagai upaya dalam memastikan apakah organisasi telah bersikap obyektif atau bebas dari pengaruh pihak-pihak yang dapat merugikan organisasi atau tidak. Dengan mampu bersikap objektif, maka peningkatan kinerja perusahaan dapat dicapai. Berdasarkan pernyataan yang tersebut, maka peneliti mengajukan hipotesis ke-empat yaitu sebagai berikut.

$\mathrm{H}_{4}$ : Independensi berpengaruh positif terhadap kinerja manajerial pada hotel berbintang di Kabupaten Badung.

Kewajaran merupakan kesetaraan serta keadilan untuk pemenuhan hak yang dimiliki oleh stakeholder yang dilandaskan kesepakatan serta peraturan undang-undang. Perusahaan diharapkan dapat menyetarakan kepentingan dan hak-hak yang dimiliki stakeholder sehingga nantinya kinerja perusahaan dapat semakin baik, sehingga diperoleh hipotesis ke-lima yaitu sebagai berikut.

$\mathrm{H}_{5}$ : Kewajaran berpengaruh positif terhadap kinerja manajerial pada hotel berbintang di Kabupaten Badung.

Budaya organisasi diyakini bisa mempengaruhi sikap dan prilaku seseorang yang berperan dalam peningkatan kinerja. Jika lingkungan kerja yang baik mampu tercapai, maka hal ini akan berpengaruh terhadap terwujudnya tujuan perusahaa. Berdasarkan hal tersebut, maka peneliti mengajukan hipotesis keenam yaitu sebagai berikut. 
$\mathrm{H}_{6}$ : Budaya Organisasi berpengaruh positif terhadap kinerja manajerial pada hotel berbintang di Kabupaten Badung.

Secara sistematis, kerangka konseptual penelitian ini disajikan pada Gambar 1 berikut ini.

Prinsip-prinsip GCG

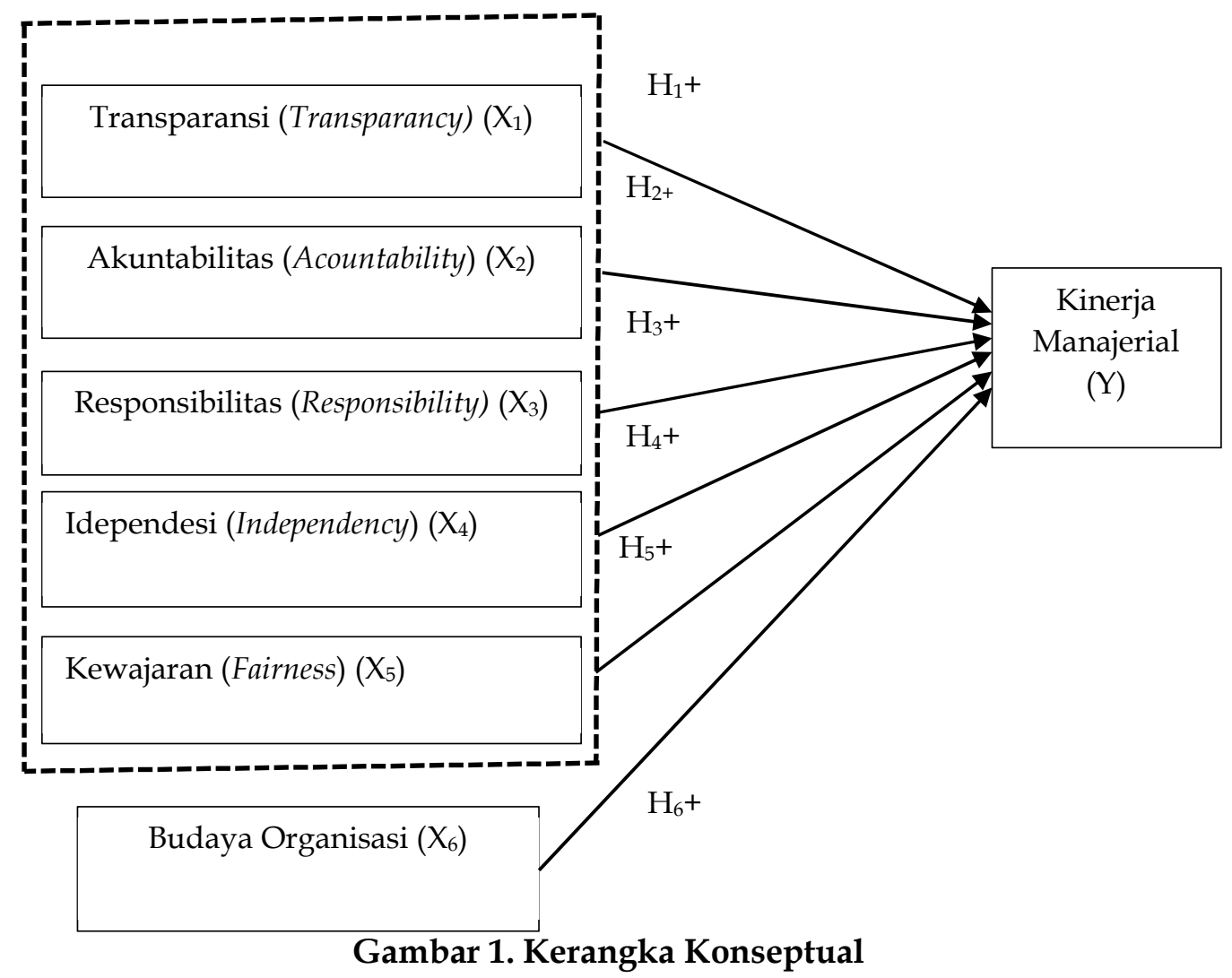

Sumber: Data Penelitian, 2019

\section{METODE PENELITIAN}

Pendekatan kuantitatif yang berbentuk asosiatif adalah pendekatan yang digunakan dalam penelitian ini. Sugiyono, (2017:64), berpendapat bahwa penelitian asosiatif adalah penelitian yang memiliki tujuan untuk mengetahui hubungan antara dua variabel atau lebih. Penelitian ini dilakukan untuk mengetahui pengaruh antara enam variabel independen yakni transparansi, akuntabilitas, responsibilitas, independensi, kewajaran, dan budaya organisasi terhadap vaiabel dependen yaitu terhadap kinerja manajerial pada hotel berbintang di Kabupaten Badung. Dari 156 jumlah hotel berbintang yang ada di Kabupaten Badung didapat sampel sebanyak 61 hotel berbintang dengan menggunakan rumus Slovin. Hotel berbintang di Kabupaten Badung diklasifikasikan berdasarkan jenis bintang, di Kabupaten Badung terdapat klasifikasi hotel berbintang yaitu, hotel bintang 1,2,3,4 dan 5. Pengambilan sampel dari masing-masing klasifikasi bintang ini diambil adalah dengan cara proportionate stratified random sampling. Metode pengumpulan data yang 
digunakan dalam penelitian ini adalah dengan menggunakan kuesioner skala likert 4 poin.

Teknik analisis yang digunakan pada penelitian ini adalah analisis regresi linier berganda. Analisis regresi linier berganda digunakan untuk mengetahui ada tidaknya pengaruh variabel independen terhadap variabel dependen. Sebelum melakukan analisis regresi linier berganda, dilakukan uji validitas dan reliabilitas terlebih dahulu. Selanjutnya dilanjutkan dengan uji asumsi klasik (uji normalitas, uji multikolinearitas, uji heteroskedastisitas), dan uji statistik deskriptif. Setelah itu, dilakukan analisis regresi linier berganda dan juga menguji Koefisien Determinasi (R2), Uji Kelayakan Model (Uji F), serta Uji Hipotesis (Uji t). Hasil analisis dijelaskan didalam persamaan regresi linier berganda yaitu sebagai berikut.

$Y=\alpha+\beta_{1} X_{1}+\beta_{2} X_{2}+\beta_{3} X_{3}+\beta_{4} X_{4}+\beta_{5} X_{5}+\beta_{6} X_{6}+\varepsilon$

Keterangan :

$\mathrm{Y}$ : Kinerja manajerial hotel berbintang

a : Bilangan konstanta

$\beta_{1}$ : Koefisien regresi transparansi

$\beta_{2}$ : Koefisien regresi akuntabilitas

$\beta_{3}$ : Koefisien regresi responsibilitas

$\beta_{4}$ : Koefisien regresi independensi

$\beta_{5}$ : Koefisien regresi kewajaran

$\beta_{6}$ : Koefisien regresi budaya organisasi

$\mathrm{X}_{1}$ : Skors dimensi variabel transpatansi

$\mathrm{X}_{2}$ : Skors dimensi variabel akuntabilitas

$\mathrm{X}_{3}$ : Skors dimensi variabel responsibilitas

$\mathrm{X}_{4}$ : Skors dimensi variabel independensi

$\mathrm{X}_{5}$ : Skors dimensi variabel kewajaran

$\mathrm{X}_{6}$ : Skors dimensi variabel budaya organisasi

$\varepsilon$ : Error term (komponen pengganggu)

\section{HASIL DAN PEMBAHASAN}

Responden dalam penelitian ini adalah General Manager Hotel Berbintang di Kabupaten Badung. Penelitian dilakukan dengan menyebar kuesioner sebanyak 61, ke Hotel Berbintang di Kabupaten Badung. Rincian pendistribusian dan pengembalian kuesioner serta informasi tingkat pengembalian kuesioner disajikan di Tabel 2, berikut.

Tabel 2. Jumlah Sampel dan Tingkat Pengembalian Kuesioner

\begin{tabular}{lcc}
\hline \multicolumn{1}{c}{ Keterangan } & Jumlah & Presentase \\
\hline Kuesioner yang disebar & 61 & 100 persen \\
Kuesioner yang kembali & 61 & 100 persen \\
Kuesioner yang tidak kembali & 0 & 0 persen \\
Kuesioner yang kembali dan layak digunakan & 61 & 100 persen \\
\hline
\end{tabular}

Sumber: Data Penelitian, 2019

Penelitian ini memiliki sampel berjumlah 61 sampel yang merupakan Hotel Berbintang di Kabupaten Badung. Setiap Hotel Berbintang diberikan satu buah kuesioner yang diisi oleh manager hotel, dari 61 kuesioner yang telah dikirim kuesioner yang kembali dan dapat digunakan berjumlah 61 kuesioner maka 
memiliki presentase pengembalian sebesar 100 persen. Instrument pada penelitian ini memiliki validasi konstruksi yang baik karena memiliki nilai positif $>0,30$. Hasil tersebut dapat dilihat pada Tabel 3.

\section{Tabel 3. Hasil Uji Validitas}

\begin{tabular}{|c|c|c|c|c|}
\hline No & Variabel & Item & $\begin{array}{l}\text { Pearson } \\
\text { Colleration }\end{array}$ & Keterangan \\
\hline \multirow[t]{4}{*}{1} & Transparasi & $\mathrm{X}_{1.1}$ & 0,968 & Valid \\
\hline & $\left(X_{1}\right)$ & $X_{1.2}$ & 0,932 & Valid \\
\hline & & $\mathrm{X}_{1.3} 3$ & 0,938 & Valid \\
\hline & & $X_{1.4}$ & 0,889 & Valid \\
\hline \multirow[t]{4}{*}{2} & Akuntabilitas & $\mathrm{X}_{2.1}$ & 0,949 & Valid \\
\hline & $\left(\mathrm{X}_{2}\right)$ & $\mathrm{X}_{2.2}$ & 0,947 & Valid \\
\hline & & $\mathrm{X}_{2.3} 3$ & 0,964 & Valid \\
\hline & & $\mathrm{X}_{2.4}$ & 0,967 & Valid \\
\hline \multirow[t]{4}{*}{3} & Responsibilitas & $X_{3.1}$ & 0,881 & Valid \\
\hline & $\left(X_{3}\right)^{+}$ & $X_{3.2}$ & 0,973 & Valid \\
\hline & & $X_{3.3}$ & 0,973 & Valid \\
\hline & & $\mathrm{X}_{3.4}$ & 0,973 & Valid \\
\hline \multirow[t]{4}{*}{4} & Independensi & $X_{4.1}$ & 0,955 & Valid \\
\hline & $\left(X_{4}\right)$ & $\mathrm{X}_{4.2}$ & 0,887 & Valid \\
\hline & & $X_{4.3}$ & 0,876 & Valid \\
\hline & & $\mathrm{X}_{4.4}$ & 0,950 & Valid \\
\hline \multirow[t]{4}{*}{5} & Kewajaran & $X_{5.1}$ & 0,927 & Valid \\
\hline & $\left(X_{5}\right)$ & $X_{5} .2$ & 0,942 & Valid \\
\hline & & $X_{5} .3$ & 0,945 & Valid \\
\hline & & $X_{5} .4$ & 0,935 & Valid \\
\hline \multirow[t]{7}{*}{6} & Budaya Organisasi & $X_{6.1}$ & 0,906 & Valid \\
\hline & $\left(X_{6}\right)$ & $X_{6.2} 2$ & 0,920 & Valid \\
\hline & & $X_{6.3}$ & 0,898 & Valid \\
\hline & & $X_{6.4}$ & 0,947 & Valid \\
\hline & & $X_{6.5}$ & 0,926 & Valid \\
\hline & & $X_{6.6} 6$ & 0,891 & Valid \\
\hline & & $X_{6.7}$ & 0,900 & Valid \\
\hline \multirow[t]{10}{*}{7} & Kinerja Manajerial & Y.1 & 0,890 & Valid \\
\hline & $(\mathrm{Y})$ & $\mathrm{Y} .2$ & 0,945 & Valid \\
\hline & & Y.3 & 0,924 & Valid \\
\hline & & Y.4 & 0,951 & Valid \\
\hline & & Y.5 & 0,930 & Valid \\
\hline & & Y.6 & 0,930 & Valid \\
\hline & & Y.7 & 0,892 & Valid \\
\hline & & Y.8 & 0,877 & Valid \\
\hline & & Y.9 & 0,930 & Valid \\
\hline & & Y.10 & 0,897 & Valid \\
\hline
\end{tabular}

Sumber: Data Penelitian, 2019

Sebuah variabel dapat disebut reliabel bila nilai Alpha Cronbach lebih besar dari 0,70, Ghozali, (2016). Variabel dalam penelitian ini menunjukkan nila Alpha Cronbach lebih besar dari 0,70 sehingga variabel dalam penelitian ini dapat dikatakan reliabel. Hasil tersebut dapat dilihat pada Tabel 4. 
Tabel 4. Hasil Uji Reliabilitas

\begin{tabular}{clcc}
\hline No & Variabel & $\begin{array}{c}\text { Koefisien Alpha } \\
\text { Cronbach }\end{array}$ & Keterangan \\
\hline 1 & Transparansi & 0,948 & Reliabel \\
2 & Akuntabilitas & 0,969 & Reliabel \\
3 & Responsibilitas & 0,964 & Reliabel \\
4 & Idependensi & 0,937 & Reliabel \\
5 & Kewajaran & 0,954 & Reliabel \\
6 & Budaya Organisasi & 0,966 & Reliabel \\
7 & Kinerja Manajerial & 0,978 & Reliabel \\
\hline
\end{tabular}

Sumber: Data Penelitian, 2019

Uji reliabilitas bertujuan untuk menguji konsistensitas dan kelayakan data yang digunakan untuk penelitian. Hasil uji reliabilitas menunjukkan bahwa seluruh instrumen penelitian memiliki koefisien Cronbach's Alpha lebih lebih besar dari 0,60. Sehingga dapat dikatakan bahwa semua instrumen dalam penelitian ini konsisten dan layak diguanakan untuk penelitian. Adapun hasil dari uji reliabilitas dapat ditunjukkan pada Tabel 4.

Tabel 5. Statistik Deskriptif

\begin{tabular}{llllll}
\hline & $\mathrm{N}$ & Min. & Maks. & Mean & Std. Deviation \\
\hline Transparansi $\left(\mathrm{X}_{1}\right)$ & 61 & 8 & 16 & 13,164 & 1,695 \\
Akuntabilitas $\left(\mathrm{X}_{2}\right)$ & 61 & 11 & 16 & 12,525 & 1,026 \\
Responsibilitas $\left(\mathrm{X}_{3}\right)$ & 61 & 11 & 16 & 13,115 & 1,439 \\
Idependensi $\left(\mathrm{X}_{4}\right)$ & 61 & 11 & 16 & 13,262 & 1,632 \\
Kewajaran $\left(\mathrm{X}_{5}\right)$ & 61 & 10 & 16 & 12,738 & 1,504 \\
Bedaya Organisasi $\left(\mathrm{X}_{6}\right)$ & 61 & 19 & 28 & 23,312 & 2,426 \\
Kinerja Manajerial $(\mathrm{Y})$ & 61 & 29 & 40 & 33,131 & 3,514 \\
\hline
\end{tabular}
Sumber: Data Penelitian, 2019

Seperti contoh pada Tabel 6, variabel transparansi $\left(X_{1}\right)$ mempunyai nilai minimum 8,00 dan nilai maksimum 16,00. Nilai rata-rata 13,0169 dan memiliki penyimpangan nilai rata-rata yang dijelaskan oleh standar deviasi 1,695. Data digunakan bedistribusi normal apabila koefisien Asymp.Sig (2-tailed) lebih besar dari 0,05. Hasil pengujian normalitas menunjukkan koefisien Asymp.Sig (2-tailed) lebih besar dari 0,05, sehingga dapat dikatakan bahwa data berdistribusi normal. Hasil pengujian dapat dilihat pada Tabel 6, sebagai berikut.

\section{Tabel 6. Hasil Uji Normalitas}

\begin{tabular}{lll}
\hline & & Unstandardized Residual \\
\hline $\mathrm{N}$ & Mean & 61 \\
Normal Parameters ${ }^{a, b}$ & Std. Deviation & 0 \\
& Absolute & 1,1435574 \\
Most Extreme Differences & Positive & 0,14 \\
& Negative & 0,14 \\
Kolmogorov-Smirnov Z & & $-0,081$ \\
Asymp. Sig. (2-tailed) & & 1,093 \\
\hline Sumb. Data Penelitin, 2019 & 0,183 \\
\hline
\end{tabular}

Sumber: Data Penelitian, 2019

Berdasarkan hasil uji multikolinearitas diperoleh nilai tolerance dari masingmasing variabel lebih besar dari 0,10 da nilai VIF dari masing-masing variabel lebih kecil dari 10, sehingga dapat dinyatakan bahwa variabel bebas pada model regresi yang ada, tidak terjadi gejala multikolinearitas. 
Tabel 7. Hasil Uji Multikolinieritas

\begin{tabular}{|c|c|c|c|}
\hline \multirow[b]{2}{*}{ Model } & \multicolumn{2}{|c|}{ Collinearity Statistics } & \multirow{2}{*}{ Keterangan } \\
\hline & Tolerance & VIF & \\
\hline Transparansi $\left(\mathrm{X}_{1}\right)$ & 0,746 & 1,341 & Tidak ada multikolinieritas \\
\hline Akuntabilitas $\left(X_{2}\right)$ & 0,928 & 1,078 & Tidak ada multikolinieritas \\
\hline Responsibilitas $\left(X_{3}\right)$ & 0,458 & 2,184 & Tidak ada multikolinieritas \\
\hline Idependensi $\left(\mathrm{X}_{4}\right)$ & 0,528 & 1,896 & Tidak ada multikolinieritas \\
\hline Kewajaran $\left(X_{5}\right)$ & 0,588 & 1,700 & Tidak ada multikolinieritas \\
\hline Bedaya Organisasi $\left(X_{6}\right)$ & 0,449 & 2,225 & Tidak ada multikolinieritas \\
\hline
\end{tabular}

Sumber: Data Penelitian, 2019

Berdasarkan Tabel 7, terlihat nilai tolerance setiap variabel lebih besar dari 0,1 dan nilai VIF lebih kecil dari 10, maka bisa dikatakan model regresi bebas dari multikolinieritas sehingga dapat digunakan dalam penelitan.

Tabel 8. Hasil Uji Heteroskedastisitas

\begin{tabular}{lcl}
\hline \multicolumn{1}{c}{ Variabel } & Sig. & \multicolumn{1}{c}{ Keterangan } \\
\hline Transparansi $\left(\mathrm{X}_{1}\right)$ & 0,763 & Bebas Heteroskedastisitas \\
Akuntabilitas $\left(\mathrm{X}_{2}\right)$ & 0,616 & Bebas Heteroskedastisitas \\
Responsibilitas $\left(\mathrm{X}_{3}\right)$ & 0,124 & Bebas Heteroskedastisitas \\
Idependensi $\left(\mathrm{X}_{4}\right)$ & 0,972 & Bebas Heteroskedastisitas \\
Kewajaran $\left(\mathrm{X}_{5}\right)$ & 0,557 & Bebas Heteroskedastisitas \\
Bedaya Organisasi $\left(\mathrm{X}_{6}\right)$ & 0,460 & Bebas Heteroskedastisitas \\
\hline
\end{tabular}

Sumber: Data Penelitian, 2019

Berdasarkan Tabel 8, diketahui bahwa nilag Sig. dari masing-masing variabel lebih besar dari 0,05 yang berarti variabel tersebut tidak mengandung gejala heteroskedastisitas. Sesudah dilakukan uji asumsi klasik kemudian dilanjutkan dengan melakukan uji regresi linear berganda yang bisa dilihat dalam Tabel 9, sebagai berikut.

Tabel 9. Hasil Uji Regresi Linear Berganda

\begin{tabular}{|c|c|c|c|c|c|}
\hline \multirow{2}{*}{ Model } & \multicolumn{2}{|c|}{$\begin{array}{l}\text { Unstandardized } \\
\text { Coefficients }\end{array}$} & \multirow{2}{*}{$\begin{array}{l}\text { Standardized } \\
\text { Coefficients } \\
\text { Beta }\end{array}$} & \multirow{2}{*}{$t$} & \multirow{2}{*}{ Sig.t } \\
\hline & B & $\begin{array}{l}\text { Std. } \\
\text { Error }\end{array}$ & & & \\
\hline (Constant) & 7,962 & 2,376 & & 3,351 & 0,001 \\
\hline Transparansi $\left(\mathrm{X}_{1}\right)$ & $-0,113$ & 0,106 & $-0,055$ & $-1,064$ & 0,292 \\
\hline Akuntabilitas $\left(X_{2}\right)$ & $-0,381$ & 0,157 & $-0,111$ & $-2,422$ & 0,019 \\
\hline Responsibilitas $\left(\mathrm{X}_{3}\right)$ & $-0,125$ & 0,160 & $-0,051$ & $-0,781$ & 0,438 \\
\hline Idependensi $\left(X_{4}\right)$ & 1,695 & 0,131 & 0,787 & 12,909 & 0,000 \\
\hline Kewajaran $\left(X_{5}\right)$ & 0,111 & 0,135 & 0,048 & 0,825 & 0,413 \\
\hline Bedaya Organisasi $\left(X_{6}\right)$ & 0,394 & 0,096 & 0,272 & 4,114 & 0,000 \\
\hline Adjusted R Square & 0,882 & & & & \\
\hline F Statistik & 75,989 & & & & \\
\hline Signifikansi & 0,000 & & & & \\
\hline
\end{tabular}

Dapat dilihat pada Tabel 9, dapat dibuat persamaan sebagai berikut. $Y=7,962-0,133 X_{1}-0,381 X_{2}-0,125 X_{3}+1,695 X_{4}+0,111 X_{5}+0,394 X_{6}$

Nilai konstanta 7,962 memperlihatkan bila variabel transparansi $\left(X_{1}\right)$, akuntabilitas $\left(X_{2}\right)$, responsibilitas $\left(X_{3}\right)$, independensi $\left(X_{4}\right)$, kewajaran $\left(X_{5}\right)$, serta budaya organisasi $\left(X_{6}\right)$ nilainya konstan, maka kinerja manajerial $(Y)$ memiliki nilai positif sebesar 7,962. Nilai koefisien regresi Transparansi $\left(X_{1}\right)$ yaitu $-0,113$, 
artinya bila transparansi naik satu satuan maka kinerja manajerial menurun 0,113 satuan, dengan asumsi variabel lainnya konstan. Nilai koefisien regresi Akuntabilitas $\left(\mathrm{X}_{2}\right)$ sebesar $-0,381$ artinya bila akuntabilitas meningkat 1 satuan maka kinerja manajerial menurun 0,381 satuan, dengan asumsi variabel lainnya konstan. Nilai koefisien regresi Responsibilitas $\left(X_{3}\right)$ adalah $-0,125$, artinya bila responsibilitas naik satu satuan maka kinerja manajerial menurun 0,125 satuan, dengan asumsi variabel lainnya konstan. Nilai koefisien regresi Independensi $\left(X_{4}\right)$, sebesar 1,695, artinya bila independensi meningkat 1 satuan maka kinerja manajerial naik 1,695 satuan, dengan asumsi variabel lainnya konstan. Hasil tersebut mengindikasikan independensi berbanding lurus dengan kinerja manajerial. Nilai koefisien regresi Kewajaran $\left(X_{5}\right)$, sebesar 0,111 , artinya bila kewajaran naik satu satuan maka kinerja manajerial akan meningkat 0,111 satuan, dengan asumsi variabel lainnya konstan. Hasil ini mengindikasikan bahwa independensi berbanding lurus dengan kinerja manajerial. Nilai koefisien regresi Budaya Organisasi $\left(X_{6}\right)$ yaitu 0,394 , artinya bila budaya organisasi naik satu satuan maka kinerja manajerial akan naik 0,394 satuan, dengan asumsi variabel lainnya konstan. Hasil ini mengindikasikan bahwa independensi berbanding lurus dengan kinerja manajerial.

Berdasarkan Tabel 9, nilai Adjusted $R$ Square yaitu 0,882 mempunya arti bahwa sebesar 88,2 persen variasi kinerja manajerial mendapat pengaruh dari variasi transparansi, akuntabilitas, responsibilitas, independensi, kewajaran, serta budaya organisasi, dan sisanya yaitu 11,8 persen dijabarkan faktor lainnya yang tidak dijelaskan didalam penelitian ini.

Hasil Uji ANOVA atau (F test) pada Tabel 9, memperlihatkan nilai F hitung yaitu 75,989 dengan signifikansi 0,000 yang lebih rendah dari alpha 0,05. Hal tersebut mengindikasikan bahwa model yang dipakai didalam penelitian ini layak. Transparansi, akuntabilitas, responsibilitas, independensi, kewajaran dan budaya organisasi secara bersamaan memiliki pengaruh terhadap kinerja manajerial.

Uji statistik $\mathrm{t}$ dilakukan dengan membandingkan hasil nilai signifikansi dengan $a=0,05$. Pengaruh Transparansi $\left(X_{1}\right)$ terhadap Kinerja Manajerial. Berdasarkan Tabel 9, hasil analisis pengaruh Transparansi terhadap Kinerja Manajerial diperoleh nilai koefisien regresi sebesar $-0,113$ dan nilai Sig. $t$ sebesar 0,292. Nilai Sig. $t$ 0,292 lebih besar dari 0,05 berarti bahwa $\mathrm{H}_{1}$ ditolak. Hasil ini mempunyai arti bahwa Transparansi memiliki pengaruh negatif dan tidak signifikan terhadap Kinerja Manajerial sehingga hipotesis pertama dalam penelitian ini ditolak. Pengaruh Akuntabilitas $\left(X_{2}\right)$ terhadap Kinerja Manajerial. Berdasarkan Tabel 9, hasil analisis pengaruh Akuntabilitas terhadap Kinerja Manajerial diperoleh nilai koefisien regresi sebesar $-0,381$ dan nilai Sig. $t$ sebesar 0,019. Nilai Sig. $t$ 0,019 lebih kecil dari 0,05 berarti bahwa $\mathrm{H}_{2}$ ditolak. Hasil ini memiliki makna yaitu Akuntabilitas memiliki pengaruh negatif dan signifikan terhadap Kinerja Manajerial sehingga hipotesis kedua dalam penelitian ini ditolak. Pengaruh Responsibilitas $\left(X_{3}\right)$ terhadap Kinerja Manajerial. Berdasarkan Tabel 9, hasil analisis pengaruh Responsibilitas terhadap Kinerja Manajerial diperoleh nilai koefisien regresi sebesar $-0,125$ dan nilai Sig. $t$ sebesar 0,438. Nilai Sig. $t$ 0,438 lebih besar dari 0,05 mengindikasikan bahwa $\mathrm{H}_{3}$ ditolak. Hasil ini mempunyai arti bahwa Responsibilitas memiliki pengaruh negative dan tidak signifikan terhadap 
Kinerja Manajerial sehingga hipotesis ketiga dalam penelitian ini ditolak. Pengaruh Independensi $\left(X_{4}\right)$ terhadap Kinerja Manajerial. Berdasarkan Tabel 9, hasil analisis pengaruh Independensi terhadap Kinerja Manajerial diperoleh nilai koefisien regresi sebesar 1,695 dan nilai Sig. $t$ sebesar 0,000. Nilai Sig. t 0,000 lebih kecil dari 0,05 mengindikasikan bahwa $\mathrm{H}_{4}$ diterima. Hasil ini berarti Independensi memiliki pengaruh positif terhadap Kinerja Manajerial jadi hipotesis keempat pada penelitian ini diterima. Pengaruh Kewajaran $\left(X_{5}\right)$ terhadap Kinerja Manajerial. Berdasarkan Tabel 9, hasil analisis pengaruh Kewajaran terhadap Kinerja Manajerial diperoleh nilai koefisien regresi sebesar 0,394 dan nilai Sig. $t$ sebesar 0,413. Nilai Sig. $t$ 0,413 lebih besar dari 0,05 berarti $\mathrm{H}_{5}$ ditolak. Hasil ini berarti Kewajaran tidak berpengaruh positif terhadap Kinerja Manajerial maka hipotesis ketiga dalam penelitian ini ditolak. Pengaruh Budaya Organisasi $\left(X_{6}\right)$ terhadap Kinerja Manajerial. Berdasarkan Tabel 9, hasil analisis pengaruh Budaya Organisasi terhadap Kinerja Manajerial diperoleh nilai koefisien regresi sebesar 1,695 dan nilai Sig. $t$ sebesar 0,000. Nilai Sig. $t$ 0,000 lebih kecil dari 0,05 mengindikasikan bahwa $\mathrm{H}_{6}$ diterima. Hasil ini berarti Budaya Organisasi memiliki pengaruh positif terhadap Kinerja Manajerial maka hipotesis keenam pada penelitian ini diterima.

\section{SIMPULAN}

Berdasarkan hasil analisis kemudian bisa didapat beberapa kesimpulan yakni, Implementasi prinsip Transparansi tidak berpengaruh pada kinerja manajerial Hotel Berbintang. Hal tersebut menjukkan implementasi prinsip transparansi di Hotel Berbintang sudah baik tetapi belum cukup mendorong peningkatan kinerja manajerial pada Hotel Berbintang sehingga hipotesis ditolak. Penerapan prinsip Akuntabilitas tidak berpengaruh pada kinerja manajerial Hotel Berbintang. Hal ini menjukkan bahwa penerapan prinsip akuntabilitas pada Hotel Berbintang belum tentu dapat mendorong peningkatan kinerja manajerial pada Hotel Berbintang sehingga hipotesis ditolak. Penerapan prinsip Responsibilitas tidak berpengaruh pada kinerja manajerial Hotel Berbintang. Hal tersebut menjukkan implementasi prinsip responsibilitas pada Hotel Berbintang sudah cukup baik tetapi masih belum dapat mendorong peningkatan kinerja manajerial pada Hotel Berbintang sehingga hipotesis ditolak. Penerapan prinsip Independensi berpengaruh positif pada kinerja manajerial Hotel Berbintang. Hal tersebut menunjukkan bahwa apabila implementasi prinsip independensi dilakukan dengan baik, maka akan meningkatkan kinerja manajerial pada Hotel Berbintang sehingga hipotesis diterima. Penerapan prinsip Kewajaran tidak berpengaruh pada kinerja manajerial Hotel Berbintang. Hal ini menjukkan bahwa penerapan prinsip kewajaran pada Hotel Berbintang sudah cukup tetapi masih belum dapat mendorong peningkatan kinerja manajerial pada Hotel Berbintang sehingga hipotesis ditolak. Penerapan Budaya Organisasi berpengaruh positif pada kinerja manajerial Hotel Berbintang. Hal ini berarti bahwa semakin baik budaya organisasi itu dilaksanakan oleh seluruh manajer Hotel Berbintang, maka kinerja manajerial pun akan akan meningkat sehingga hipotesis diterima.

Berdasarkan hasil penelitian maka terdapat beberapa saran yakni, Implementasi GCG dan budaya organisasi merupakan hal yang dapat mendorong tercapainya kinerja yang lebih baik, maka disarankan Hotel Berbintang di 
Kabupaten Badung dapat menjaga serta meningkatkan implementasi GCG dan budaya organisasi tersebut. Idependensi adalah prinsip GCG bisa dikatakan dominan diperhatikan jadi diperlukan adanya keseimbangan penerapan prinsipprinsp GCG lainnya. Budaya organisasi adalah salah satu faktor pendorong meningkatnya kinerja manajerial pada hotel berbintang, untuk itu hotel berbintang disarankan dapat meningkatkan budaya yang baik dalam organisasinya.

\section{REFERENSI}

Azeez, A. A. (2015). Corporate governance and Firm Performance $\square$ : Evidence from Sri Lanka Corporate governance and Firm Performance $\square$ : Evidence from Sri Lanka. Journal of Finance and Bank Management, 3(1), 180-189. https:// doi.org/10.15640/jfbm.v3n1a16

Badan Pusat Statistik Kabupaten Badung. (2017). Tingkat Penghunian Kamar Hotel Kabupaten Badung.

Clemente, \& Labat. (2009). Corporate governance Mechanisms And Voluntary Disclosure. The Role Of Independent Directors In The Boards Of Listed Spanish Firms, 1-50.

Donaldson, L., \& Davis, J. H. (1991). Stewardship Theory or Agency theory:, (June 1991), 49-65.

Eisenhardt, K. M. (1989). Agency theory: An Assessment and Review. The Academy of Management Review, 14(1), 57-74.

El-Chaarani, H. (2014). The Impact Of Corporate governance On The Performance Of Lebanese Banks. The International Journal of Business and Finance Research, 8(5), 35.

Ghozali, I. (2016). Aplikasi Analisis Multivariete dengan Program IBM SPSS 21. Semarang: Badan Penerbit Universitas Diponegoro.

Jensen, M. C., \& Meckling, W. H. (1976). Theory Of The Firm $\square$ : Managerial Behavior, Agency Costs And Ownership Structure. Journal of Financial Economics, 3, 305-360.

Mahoney, M. J. (1987). Scientific Publication and Knowledge Politics.

Megawati, N. L. A., Dewi, P. E. D. M., \& Herawati, N. T. (2017). Pengaruh Implementasi Prinsip-Prinsip Good Corporate governance (GCG), Budaya Organisasi, dan Gaya Kepemimpinan Terhadap Kinerja Hotel Berbintang di Kabupaten Buleleng. E-Journal S1 Ak Pendidkan GAnesha, 8(2).

Messier, W. F., Glover, S. M., \& Prawitt, D. F. (2012). Auditing \& Assurance Services. Nurani, T. (2012). Pengaruh Motivasi Kerja, Kepemimpinan dan Budaya Organisasi Terhadap Kinerja Karyawan Perusahaan (Studi Kasus di Lingkungan Kantor PDAM Se-Eks Karesidenan Surakarta). Jurnal UMS. Fakultas Ekonomi Universitas Muhammadiyah Surakarta.

Oliver, M. S., \& Horngren, C. T. (2010). Managerial Accounting. American: Natalie E. Anderson.

Pradnyaswari, L. G. D. A., \& Putri, I. G. A. M. A. D. (2016). pengaruh PrinsipPrinsip Good Corporate governance pada Kinerja Keuangan Koperasi di Kabupaten Klungkung. E-Jurnal Akuntansi Universitas Udayana, 14(2), 10641091.

Putri, N. K. D. Y., \& Putra, I. M. P. D. (2017). Pengaruh Prinsip-Prinsip Good 
Corporate governance, Motivasi, Dan Budaya Organisasi Terhadap Kinerja Karyawan. E-Jurnal Akuntansi Universitas Udayana, 21(2), 1660-1688.

Rambo, C. M. (2013). Influence of The Capital Markets Authority's Corporate governance Guidelines on Financial Performance of Commercial Banks in Kenya. The International Journal of Business and Finance Research, 7(3), 77-92.

Riyadi, S., \& Yulianto, A. (2014). Pengaruh Pembiayaan bagi Hasil, Pembiayaan Jual Beli, Financing to Deposit Ratio (FDR) dan Non Performing Financing (NPF) terhadap Profitabilitas Bank Umum Syariah di Indonesia, 3(4), 466474.

Robbins, Stephen, \& Coulter, M. (2010). Management sixth edition, Prentice hall, Inc. Engewood clift, NJ 07632.

Sari, T. Y. (2017). Pengaruh Penerapan Prinsip Good Corporate governance terhadap Kinerja Perusahaan pada Perusahaan BUMN Kota Palembang.

Sugiyanto. (2011). Implementasi Teori Keagenan Sebagai Dasar Memperbaiki Partisipasi Anggota Koperasi.

Sugiyono. (2017). Metode Penelitian: Kualitatif, Kuantitatif, dan $R$ \& D. Bandung: Alfabeta Bandung.

Temaja, I. P. E. A. W., \& Utama, I. M. K. (2016). Pengaruh Profesionalisme, Kepribadian Hardiness, Motivasi dan Budaya Organisasi pada Kinerja Auditor di Kantor Akuntansi Publik. E-Jurnal Akuntansi Universitas Udayana, 15(3), 1711-1739.

Tseng, S. (2010). The correlation between organizational culture and knowledge conversion on corporate performance, 14(2), 269-284. https://doi.org/10.1108/13673271011032409

Utami, N. L. S. A., Sujana, E., \& Yuniarta, G. adi. (2017). Pengaruh Implementasi Prinsip-Prinsip Good Corporate governance, Pengendalian Internal, Budaya Organisasi Dan Efisiensi Night Auditor Terhadap Kinerja Hotel Berbintang di Kabupaten Buleleng. E-Journal S1 Ak Pendidkan Ganesha, 7(1).

Wallach, \& Ellen. (1983). Individuals and Organizations: The Cultural Match". Training and Development Journal, 29-36.

Wirawan, A. A. G. B. P., \& I.G.A.M Asri Dwija Putri. (2018). Pengaruh Penerapan Prinsip-Prinsip GCG dan Manajemen Risiko Pada Kinerja Keuangan Koperasi di Kabupaten Gianyar. E-Jurnal Akuntansi Universitas Udayana, 23(3), 1791-1818.

Yazdanfar. (2013). Profitability determinants among micro firms: Evidence from swedish data. Journal of Managerial Finance, 9(2), pp: 151160.

Zakaria, Z., Purhanudin, N., Yamuna, \&, \& Palanimally, R. (2014). Board Governance and Firm Performance: A Panel Data Analysis. Journal of Business Law and Ethics, 2(1), 1-12. 